Supplement of Atmos. Chem. Phys., 16, 9067-9087, 2016

http://www.atmos-chem-phys.net/16/9067/2016/

doi:10.5194/acp-16-9067-2016-supplement

(C) Author(s) 2016. CC Attribution 3.0 License.

(c) (1)

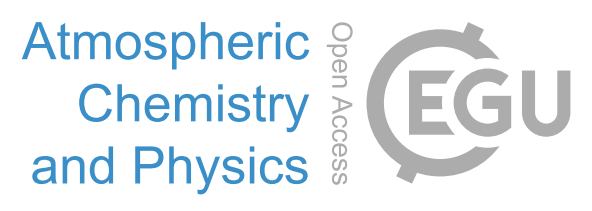

Supplement of

\title{
Ice nucleating particles in the Saharan Air Layer
}

Yvonne Boose et al.

Correspondence to: Yvonne Boose (yvonne.boose@env.ethz.ch) and Zamin A. Kanji (zamin.kanji@env.ethz.ch)

The copyright of individual parts of the supplement might differ from the CC-BY 3.0 licence. 


\section{PCVI characterization}

Characterization of the transmission efficiency of the PCVI was carried out using the method described by Kupiszewski et al. (2015) and was conducted as follows: Arizona Test Dust (ATD) was dispersed using a Solid Aerosol Generator (SAG 410; Topas GmbH, Germany). The ATD-containing sample flow was subsequently transmitted through a mixing chamber in order 5 to reduce fluctuations in the aerosol concentrations resulting from variability in the output rate of the aerosol. A valve was used to direct the flow alternatingly through the PCVI or through a bypass, with each run lasting $30 \mathrm{~s}$. The number size distributions of the particles thus transmitted were measured in the range of $0.5-20 \mu \mathrm{m}$ aerodynamic diameter using an Aerodynamic Particle Sizer (APS; model 3321, TSI, USA). The size distributions measured downstream of the PCVI were corrected for particle enrichment in the PCVI, which is given by a factor approximately equal to the ratio of the inlet flow to the outlet

10 flow of the PCVI (Boulter et al., 2006). Finally, the transmission efficiency as a function of particle size was determined by taking the ratio of the enrichment-corrected size distribution downstream of the PCVI to the size distribution downstream of the bypass (see Fig. 1). 


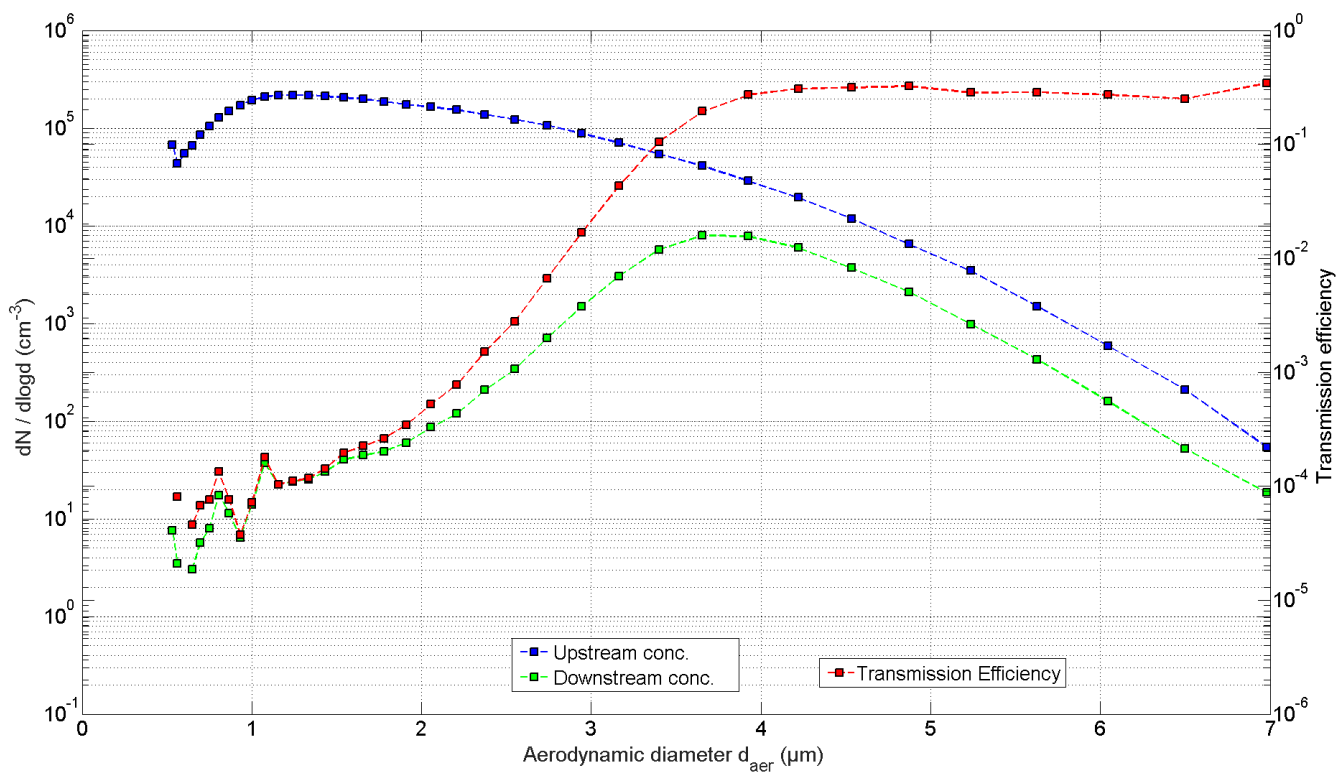

Figure 1. Particle concentration and transmission efficiency of the PCVI.

\section{References}

Boulter, J. E., Cziczo, D. J., Middlebrook, A. M., Thomson, D. S., and Murphy, D. M.: Design and Performance of a Pumped Counterflow Virtual Impactor, Aerosol Sci. Technol., 40, 969-976, doi:10.1080/02786820600840984, 2006.

Kupiszewski, P., Weingartner, E., Vochezer, P., Schnaiter, M., Bigi, A., Gysel, M., Rosati, B., Toprak, E., Mertes, S., and Baltensperger, U.: The Ice Selective Inlet: a novel technique for exclusive extraction of pristine ice crystals in mixed-phase clouds, Atmos. Meas. Tech., 8 , 3087-3106, doi:10.5194/amt-8-3087-2015, 2015. 